\title{
歯周疾患における免疫系細胞の動態に 関する免疫組織学的研究
}

\author{
2. ランゲルハンス細胞の動態 \\ 宮武祥子原宜興前田勝正 \\ 赤峰 昭文相田宜利青野正男 \\ 九州大学歯学部歯科保存学第 1 教室 \\ （主任 : 青野正男教授） \\ (昭和 60 年 12 月 19 日受付)
}

\section{Immunohistological Study on Movement of Immune Cells in Periodontitis}

\section{Movement of Langerhans Cells in Periodontitis Gingiva}

\author{
Sachiko MIYATAKE, Yoshitaka HARA, Katsumasa MAEDA, \\ Akifumi AKAMINE, Yoshitomi AIDA and Masao AONO \\ Department of Periodontics and Endodontics, Faculty of Dentistry, Kyushu University
}

(Chief : Prof. Masao Aono)

Although Langerhans cell (LC) is one of the important immune cells, the function of LC still remains indistinct in periodontitis because of few reports about it. In order to explore the roles of LC in periodontitis, we studied on the movement of LC population in oral epithelium through patients' generation and the degrees of inflammation.

For this study, fifty-two patients with periodontitis were selected and their gingiva of seventy-eight lesions were biopsid at surgical treatment or tooth extraction. The clinically healthy gingiva and gingiva affected by gingivitis were used as control. The patients were divided into three groups by their age; younger, middle and older generation. LCs were indicated immunohistochemically by their reactivity to $\mathrm{S}-100$ protein. The ratios of LCs to epithelial cells by number were determined in each generation and in each degree of inflammation.

The results obtained were as follows.

According to the severity of inflammation, the number of LCs tended to increase in every generation. Comparing the ratios of LCs in periodontitis with those in control, only in older generation significantly higher ratio was observed. Further there was no difference in younger generation.

The results indicated that LCs functioned as antigen-presenting cells also in inflammed gingiva. In addition, a possibility was suggested that the conditions of inflammation in younger generation were slightly different from those in other generations.

Key words : Periodontitis, Langerhans cell, S-100 protein, Peroxidase anti-peroxidase method

要旨 : 辺縁性歯周炎の発症年代と炎症の程度によって, ランゲルハンス細胞 (LC) の動態に相違があるかどうかにつ いて検索を行った。慢性辺縁性歯周炎罹患歯肉 52 症例, 78 部位について, ウサギ抗ヒト S-100 蛋白を一次抗体とした ペロキシダーゼ 抗ーペロキシダーゼ (PAP) 法を用いて, 歯肉上皮内の LC を同定し, 上皮細胞中に占めるその割合を

本論文の一部は, 第 28 回春季日本歯周病学会総会（1986 年 6 月 6 日）において報告した。 
算出した。対照には臨床的健康歯肉および歯肉炎罹患歯肉を用いた。その結果, LC は炎症性細胞浸潤が多くなる程増 加する傾向があった。辺縁性歯周炎と対照群とでは，高年層の場合に限り，前者に有意に多く，若年層と対照群とでは 有意差はなかった。これらのことから LC は炎症歯肉において抗原提示細胞としての機能を発揮しているものと考えら れ，さらに若年層の辺縁性歯周炎は中高年層のそれと病態が若干異なる可能性が示唆された。

索引用語：辺縁性歯周炎, ランゲルハンス細胞, S-100 蛋白, PAP 法

\section{緒言}

ランゲルハンス細胞 (LC) は, 近年注目を浴びてきて いる免疫担当細胞の一つであり, ヒト組織では, 表皮 ${ }^{1 \sim 31}$, 真皮 ${ }^{2,3)}$, リンパ節 ${ }^{4 \sim 6)}$, 胸腺 ${ }^{7)}$ などに存在している。超微 形態的には, 樹枝状突起を有し, 細胞質の電子密度の低 い細胞で，核はしばしば不整な陥入を伴っており り2,8), Birbeck 顆粒と呼ばれる特徵的な細胞質内小器官 $\left.{ }^{9}\right)$ が細 胞同定の決め手となる。しかし，LCの機能については 現在まで十分に明らかにされているとはいえない。抗原 物質を捕捉する点 ${ }^{10)}$, 細胞表面に IgG の Fcレセプター や $\mathrm{C}_{3}$ レセプターを保有し ${ }^{11)}$, Ia 抗原が存在する点 ${ }^{12 \sim 14)}$, また，同種リンパ球混合培養に拧いてTリンパ球增殖を 引き起こす点 ${ }^{15)}$ などの断片的な報告を総括して，マクロ ファージ同様, 抗原提示細胞としての機能を有すること が示唆されているにすぎない16 18)。Raush ら ${ }^{19)} は$ L LC とリンパ節の interdigitating reticulum cell との超微 形態的類似性から，LC は皮膚で刺激抗原を捕捉し，真皮 を通過後, リンパ管内に入ってリンパ節に到着し，そこ で Tリンパ球にその抗原を提示するのではないかと推測 している。

一方, 辺緑性歯周炎の発症と進展には免疫反応が大き く関与するとされ，組織学的にも免疫学的手技を用いた 報告が多くなされている。しかし，重要な免疫担当細胞 の一つである LC については, 歯周領域での研究はまだ 数少なく, LC の関与そのものも不明のままのようであ る。

そこで今回我々は, LC の辺縁性歯周炎における役割 を探る端緒として, 炎症の程度および発症年代によって その動態に相違があるか否かについて免度組織学的検索 を行った。

\section{材料および方法}

材料および方法は先に発表した報告 ${ }^{20)}$ 亿準じる。すな わち，歯周外科処置ないし抜歯時に採取した辺緑性歯周 炎罹患歯肉を $10 \%$ ホルマリン溶液で 48 時間前後固定し
た後，通法に従い約 $4 \mu$ のパラフィン切片を作製した。 このうち 1 枚には H.E. 染色を行い, 別の切片にウサギ 抗ヒト S-100 蛋白を一次抗体とした PAP 染色 (DAKO 社製 PAP Kit）を施した。内因性ペロキシダーゼの阻止 には $3 \%$ 過酸化水素水を用いた。二次抗体にはブタ抗ウ サギ免疫グロブリンを使用し，さらにウサギ抗ペロキシ ダーゼ抗体からなる PAP complex を架橋させた。これ に 3-amino=9-ethylcarbazole (AEC) を発色剂として 使用した。また対比核染色としてへマトキシリン染色を 行った。なお, 対照として, 矯正便宜抜去時の臨床的健 康歯肉と残根抜去時の歯肉炎罹患歯肉を用いた。

染色後の切片は, 400 倍光学顕微鏡下に, 接眼ミクロメ ーター $(7 \times 7 \mathrm{~mm}$ ，オリンパス社製 $)$ を用いて歯肉上皮 内の LC の数を測定し，上皮細胞中に占めるその割合を 算出した。これを各年代および炎症性細胞浸潤の程度に よって細分し， $\mathrm{t}$-検定を用いて統計処理を行い比較検討 した。年代については, 35 歳以下を若年層 (24 部位 12 名), 36 歳から 50 歳を中年層 (33 部位 23 名), 51 歳以上 を高年層 (21 部位 17 名) とした。炎症性細胞浸潤の程 度については以下の 3 段階に分けた。細胞浸潤 (一) は, 炎症性細胞が上皮下に僅かに存在するのみで, 膠原線維 の破壊は全く認めないものである。次に, 結合組織の一 部に炎症性細胞の集簇を認めるが，粘膜固有層全域には 広がっていないものを細胞浸潤 (十) とし, 細胞浸潤 （）は，炎症性細胞がほぼ粘膜固有層全域に浸潤し, 膠原線維の破壊が影著なものとした。

\section{結 果}

歯肉上皮の有棘細胞層に存在し, S-100 蛋白陽性の樹 枝状細胞を LC と同定した。この細胞は, 細胞質, 核と もに S-100 蛋白陽性であり, 核の形状は円形から不整形 で，上皮細胞閒に複数の突起を伸ばしており，メラニン 顆粒は認められなかった。一方, メラノサイトも S-100 蛋白に弱陽性に反応寸ることがあった。この細胞は基底 層に存在することが多く, 核は円形ないし楕円形で, 細 胞質突起はなく, 細胞質内にメラニン顆粒をもつことが あった。同定困難な細胞は検索対象から除外した。 


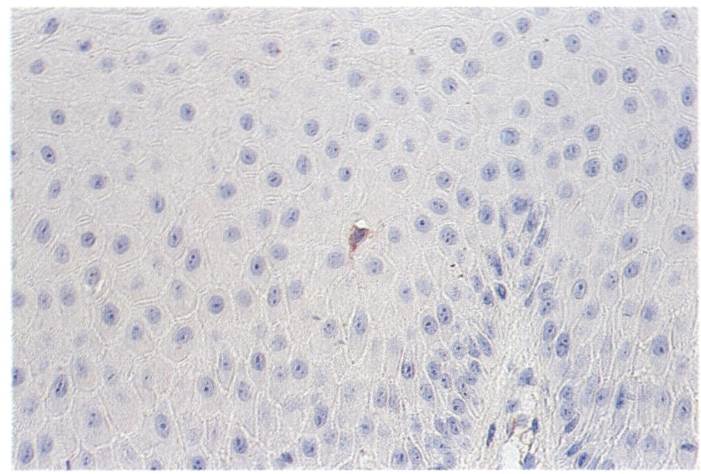

図 1 辺縁性歯周炎の若年層, 細胞浸潤 (一) の症 例にみられる LC, LC は上皮細胞間に突起を 伸ばした S-100 蛋白陽性の樹枝状細胞であ る。PAP 染色。 $\times 400$

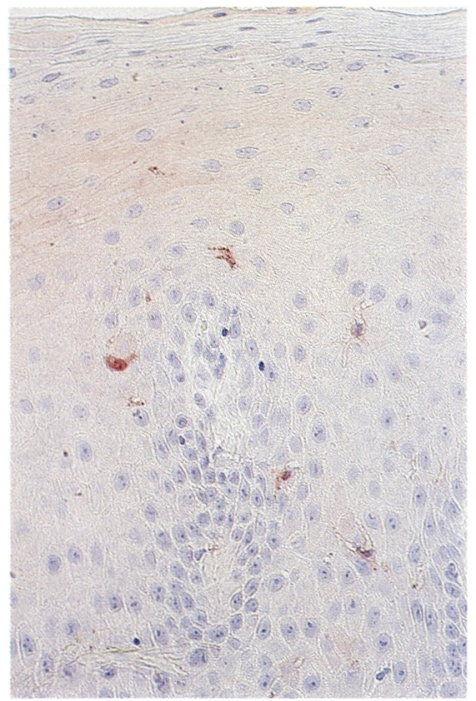

図 2 辺縁性歯周炎の中高年層, 細胞 浸潤（H）の症例にみられる LC, 図 1 に比べると, LC の数 が多く樹枝状形態もより明確で ある。PAP 染色。 $\times 400$

表 1 S-100 蛋白保有細胞の上皮細胞に 占める割合（\%)

\begin{tabular}{cccc}
\hline & & 若年 層 & 中高年層 \\
\hline 細胞浸 & - & 0.8 & 0.6 \\
潤程度 & + & 0.8 & 1.1 \\
& + & $1.1^{*}$ & $2.0^{*}$ \\
\hline 平 & 均 & 0.9 & 1.1 \\
\hline
\end{tabular}

*：危険率 $5 \%$ で有意差あり

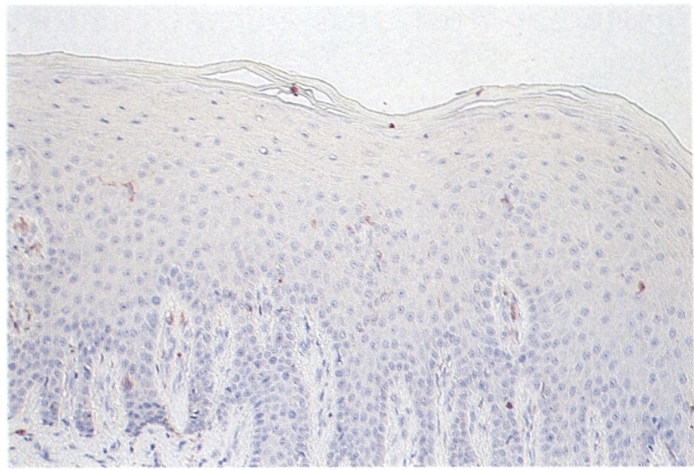

図 3 歯冠周囲炎の症例に扔いて, 上皮細胞間に多 数みられる LC。PAP 染色。 $\times 200$

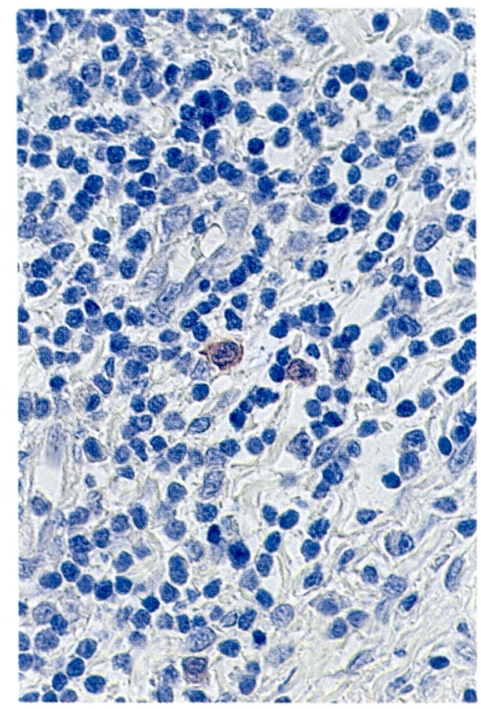

図 4 上皮直下のリンパ球集簇部にお いてリンパ球と接する LC, 核 は不整形であるが, 細胞質突起 は明確でない。PAP 染色。 $\times 1000$

はじめに, 細胞浸潤程度が変化した場合に, LC の数に 変動があるか否かを検討した。すると，LC は細胞浸潤 が高度である程多数存在していた（図 1, 図 2)。さらに 数の増加のみならず, LC の細胞質突起が比較的長く, そ の数も多くなり，より明確な樹枝状形態をとっているこ とが観察された。

次に年代別比較では，若年層より中高年層の方が多い 傾向にあった。特に細胞浸潤（H）の場合，若年層での 割合は $1.1 \%$, 中高年層の平均は $2.0 \%$ で, 危険率 5\% で 両者間に有意差がみられた（表 1)。また辺縁性歯周炎と 対照群との比較では，高年層に有意の増加が認められた 
（ $\mathrm{p}<0.05 ）$ が，若年層と対照群との比較では有意差はな 加た。

歯冠周囲炎の症例は，歯肉ポケット形成がみられるた め対照群からは除外したが, 細胞質, 核ともに S-100 蛋 白陽性でかつ上皮細胞間に細胞質突起を伸ばしている LC が有棘層に多数観察された（図 3)。上皮細胞中に占 めるその比率は $2.1 \%$ であった。

また，上皮直下のリンパ球集簇部において，丸味を帯 びた S-100 蛋白陽性細胞がリンパ球と接している像も 観察された (図 4)。この細胞の核, 細胞質ともに S-100 蛋白陽性であり，核は凸凹を伴った不整形であるが細胞 質突起は明確でなかった。組織学的特徴が神経鞘細胞と は明らかに異なるため, この細胞は LC であろうと判断 した。

\section{考察}

LC と炎症の関係については, 1973 年, Silberberg ら ${ }^{21}$ がアレルギー性皮膚炎において LC とリンパ球様単核細 胞が密接する像 (apposition) を観察したことに始まる。 次いで, LC がこうした抗原物質に対して特異な親和性 をもち, これを取り込むこと的, 皮膚の抗原刺激後, 真 皮のリンパ管に LC が出現し，さらにリンパ節およびそ の輸入リンパ管内にも Birbeck 顆粒をもつ細胞が出現 してくること22,23)などが報告されてきた。さらにその後 の研究で, LC の免疫学的性質も明らかにされてきてお り，Fc レセプター， $\mathrm{C}_{3}$ レセプターおよび Ia 抗原を有 $乙^{11 \sim 14)}$, 同種リンパ球混合培養に扔いてTリンパ球増殖 を引き起こすこと备)などから，マクロファージとの機能 の類似性がクローズアップされた ${ }^{16 \sim 18)}$ 。さらには, リン パ節の interdigitating reticulum cell との超微形態的 共通性も示唆され ${ }^{19)}$, 現在では, LC は表皮内において抗 原を捕捉し，その抗原情報をリンパ節内の $\mathrm{T}$ 領域におい て Tリンパ球に提示する機能があると推測されてい る ${ }^{24)}$ 。

一方, 歯周病学の分野においても, LC の機能を探るう えで興味深い報告がある。Bos \& Burkhardt ${ }^{25)}$ は, 無菌 マウスに oral flora を形成させると口腔上皮の LC の数 が増加すると述べ, Newcomb ら $^{26)}$ は, 七下健康歯肉に プラークが蓄積するにつれて LC の数が増加すると報告 した。さらに, DiFranco ら ${ }^{27)}$ は, 歯肉上皮の LC の数は 臨床的健康歯肉よりも辺縁性歯周炎罹患歯肉の方に多 く，その形態も炎症が存在する場合の方がより樹枝状形 態が明確になっていることを観察している。
こうした事実から，LCが歯肉の炎症と密接に関連し ていることが容易に推測されるが，この分野での研究は いまだに少数である。そこで今回我々は，辺縁性歯周炎 における LC の動態に，歯肉の炎症の程度および年代に よる変化があるのではないかという仮説をたて，本研究 を遂行した。

検索を始めるに当り，まず LC の同定法について考察 した。本来 LC は, Langerhans ${ }^{1)}$ がヒトの皮膚を塩化金 で染色した際に発見されたものであるが，その後研究が 進むにつれ種々の同定法も用いられるようになってき た。例えば，オスミウム沃化亜鉛によるもの ${ }^{28,29)}, \mathrm{L}$ dopa の取り込みによるもの ${ }^{30)}$, ATPase によるもの ${ }^{31 ~ 34)}$ などがある。しかし，現在同定の決め手となっているの は, Birbeck ${ }^{9)} に よ り$ 発見された LC に特異的な細胞質内 小器官である Birbeck 顆粒である。近年，上皮内での S-100 蛋白陽性の樹枝状細胞の透過型電顕像に, Birbeck 顆粒の存在することが証明されたため, S-100 蛋白を LC のマーカーとして使用した報告35 37) みみられる。さらに は, LC に Ia 抗原の存在が報告され，これを免疫組織学 的検索に利用したもの ${ }^{14)}$ もり，また，モノクローナル 抗体での研究の進歩により, LC が細胞表面に OKT 6 と 反応する抗原をもつこと融が確認され，これも鑑別に利 用されるようになった。DiFranco ら ${ }^{27)}$ は，この OKT 6 を利用した LC の同定が最良であると述べている。

しかし, 今回の研究では, 先に発表した検索 ${ }^{20)}$ と同時 に行い，年代抒よび炎症程度の他に，免疫グロブリン保 有細胞との関係の中で LC の動態を追求しょうと考えた ため, あえてパラフィン連続切片での S-100 蛋白によ る PAP 法を採用した。本来ならば, LC の同定には電顕 的に Birbeck 顆粒の存在を認めるべきところであろう が，今回は Nakajima らの報告37)を参考にして LC を同 定した。すなわち，メラノサイトは光顕レベルの観察で は S-100 蛋白陰性䐞陽性であることと，上皮内での存 在部位㧍よび形態から LC と区別した。

今回の検索で LC と炎症の関係についてみてみると， 辺縁性歯周炎では年代にかかわらず，炎症程度が強くな るにしたがって LC の数が増加していた。従って, LC は炎症の開始時（プラークの蓄積開始時）のみならず, 進行している場合にもその数が多いことが分る。

ところで, このような LC の数の変化は何に起因する ものであろうか。LC は骨髄由来の単核細胞を前駆細胞 とするとされており ${ }^{16,39,40)}$, Hoefsmit ら ${ }^{41)}$ によると,こ れが上皮内に移動してゆき，角化上皮中の何らかの微小 環境のせいで Birbeck 顆粒をもつに到るのではないか 
としている。上皮内で分裂増殖する LC の割合はごく僅 かという報告 ${ }^{42)}$ も㐫り, LC の数の変化は結合組織の方 から上皮内一移動してくるためではないかと思われる。 少なくともこの検索を行った症例中には, 上皮内での LC の核分裂像は認められなかった。これはやはり，プ ラークによる抗原刺激によって歯肉上皮内に誘導された と考えるべきであろう。このことは, 歯冠周囲炎の症例 に LC の数が多いことからも裏付けられる。すなわち, 歯冠周囲炎の場合, 歯肉ポケット内のプラークによる抗 原刺激を常に受けている点で, 辺縁性歯周炎と同様の状 況下にあると考えられるためである。

最後に, 年代別にみてみると, 今回の検索では, 辺縁 性歯周炎の若年層と中高年層では LC の上皮細胞に対す る割合が有意に低下していた。また, 辺縁性歯周炎と対 照群との比較では, 高年層の場合のみ前者に有意に多 く, 若年層の場合は数值上大差なかった。しかし, これ は若年層に打ける辺縁性歯周炎と対照群の病態の類似性 を示すものではない。なぜなら, 若年層の辺縁性歯周炎 の各免疫グロブリン保有細胞およびその他の細胞の比率 からすると, 中高年層のそれと近似しており20), 対照群 とは明らかに病態が異なっているからである。

このように LC の数が年代別に異なっていた原因につ いては定かでない。岡田ら ${ }^{43)}$ は, 限局型若年性歯周炎の 症例で活性型 $\mathrm{T}$ リンパ球 (OK Ia $1^{+}$の T リンパ球) が 有意に低下していたと報告して抢り, 我々の得た結果と 何らかの関連性を示唆するものかもしれないが, 即断は 避けるべきであろう。しかし観点を変えると, LC の数 が低下していた事実から, 若年層の辺縁性歯周炎におい ては, 中高年層における辺縁性歯周炎の発症と経過とは 若干異なる一面が存在するようである。

\section{結 論}

辺縁性歯周炎の発症年代および炎症の程度によって, LC の動態がどのように異なるかについて以下の検索を 行った。

辺縁性歯周炎罹患歯肉 52 症例, 72 部位, 対照として臨 床的健康歯肉および歯肉炎罹患歯肉 19 症例, 22 部位を 採取した。これらの被検材料は通法に従い, パラフィン 連続切片を作製し, 1 枚に H.E. 染色を, 別の 1 枚にウサ ギ抗ヒト S-100蛋白を一次抗体としたペロキシダーゼ 抗一ペロキシダーゼ (PAP) 法を施した。得られた標本 から歯肉上皮中の S-100 蛋白陽性の LC の数を測定し, 上皮細胞に占めるその割合を算出した。また，患者をそ
の年齢によって, 35 歳以下の若年層, 36 歳以上 50 歳以 下の中年層, 51 歳以上の高年層に分け, さらに各世代 ごとに, 炎症性細胞浸潤の程 度によって, 浸潤 $(-)$, (+)，(H）に分けた。

得られた結論は以下の通りである。

1. 上皮細胞に占める LC の数の比率の平均値は, 若 年層, 中年層, 高年層の順に, $0.9 \%, 0.9 \%, 1.4 \%$ であ り，高年層になる程増加する傾向にあった。

2. 辺縁性歯周炎の全ての年齢層において, 炎症性細 胞浸潤が多くなる程, LC の数は増加していた。

3. 炎症性細胞浸潤が (H) の場合, 若年層の平均は $1.1 \%$, 中高年層の平均は $2.0 \%$ で, $5 \%$ の危険率で有意 差があった。

4. 高年層に限った場合, 辺縁性菌周炎での平均は $1.4 \%$, 対照群での平均は $0.9 \%$ で, $5 \%$ の危険率で有意 差があった。

本研究の一部は, 昭和60年度文部省科学研究費, 奖励研究(A) (課題番号 60771588) および総合研究(A) (59370044) によった。

\section{文献}

1) Langerhans, P. : Über die Nerven der menschlichen Haut. Virchows Arch. Path. Anat. Physiol., 44 : 325-337, 1868.

2) Zelickson, A.S. : The Langerhans cell. J. Invest. Dermatol., 44 : 201-212, 1965.

3) Hashimoto, K., Tarnowski, W.M. : Some new aspects of the Langerhans cell. Arch. Dermatol., $97: 450-464,1968$.

4) Jimbow, K., Sato, S., Kukita, A. : Cells containing Langerhans granules in human lymph nodes of dermatopathic lymphadenopathy. J. Invest. Dermatol., 53 : 295-299, 1969.

5) Hoshino, T., Gotoh, T., Takeda, M. : Birbeck granules (Langerhans cell granules) in reticular cells with specialized intercellular junctions in human fetal lymph nodes. J. Electron Microscopy, $20:$ 204-205, 1971.

6) Vernon, M.L., Fountain, L., Krebs, H.M., Horta-Barbosa, L., Fuccillo, D.A., Sever, J.L. : Birbeck granules (Langerhans' cell granules) in human lymph nodes. Amer. J. Clin. Path., $60: 771-779,1973$. 
7) Hoshino, T., Kukita, A., Sato, S. : Cells containing Birbeck granules (Langerhans cell granules) in human thymus. J. Electron Microscopy, $19: 271-276,1970$.

8）奥村一彦, 武山治雄, 遠藤慶一, 黒田延彦, 中谷 伸家, 内海順夫 : 歯肉上皮におけるランゲルハン ス細胞の微細構造について. 城歯大紀要, $13: 38-$ 43, 1984.

9) Birbeck, M.S., Breathnach, A.S. and Everall, J.D. : An electron microscopic study of basal melanocytes and high level clear cells (Langerhans cells) in vitiligo. J. Invest. Dermatol., 37 : 51-63, 1961.

10) Shelley, W.B., Juhlin, L. : Langerhans cells form a reticuloepithelial trap for external contact antigens. Nature, $261: 46-47,1976$.

11) Stingl, G., Wolff-Schreiner, E.C., Pichler, W. J., Gschnait, F., Knapp, W., Wolff, K. : Epidermal Langerhans cells bear $\mathrm{Fc}$ and $\mathrm{C}_{3}$ receptors. Nature, $268: 245-246,1977$.

12) Klareskog, L., Tjernlud, U.M., Forsum, U., Peterson, P.A. : Epidermal Langerhans cells express Ia antigens. Nature, $268: 248-250,1977$.

13) Stingl, G., Katz, S.I., Shevach, E.M., Wolffschreiner, E. and Green, I. : Detection of Ia antigens on Langerhans cells in guinea pig skin. J. Immunol., 120 : 570-578, 1978.

14) Rowden, G., Lewis, M.G., Sullivan, A.K. : Ia antigen expression on human epidermal Langerhans cells. Nature, $268: 247-248,1977$.

15) Stingl, G., Katz, S.I., Green, I. and Shevach, E.M. : The functional role of Langerhans cells. J. Invest. Dermatol., $74: 315-318,1980$.

16) Stingl, G., Tamaki, K. and Katz, S.I. : Origin and Function of epidermal Langerhans cells. Immunological Rev., 53 : 149-174, 1980.

17) Thorbecke, G.J., Silberberg, S.I. and Flotte, T.J. : Langerhans cells as macrophages in skin and lymphoid organs. J. Invest. Dermatol., 66 : 210-217, 1976.

18）星野 洸, 小林身哉：ランゲルハンス細胞と免疫. 細胞, $12: 132-140,1980$.

19) Rausch, E., Kaiserling, E. and Goos, M. : Langerhans cells and interdigitating reticulum cells in the thymus-dependent region in human dermatopathic lymphadenitis. Virchows Arch. B Cell Path., 25 : 327-343, 1977.

20）原 宜興，吉村祥子，前田勝正，赤峰昭文，相田 宜利, 青野正男 : 歯周疾患における免疫系細胞の 動態に関する免疫組織学的研究 1 . 世代別にみた 免疫グロブリン保有細胞の比率. 日歯周誌, 27 : 795-806, 1985.

21) Silberberg, I. : Apposition of mononuclear cells to Langerhans cells in contact allergic reactions. Acta Dermatovener (Stockholm), 53 : 1$12,1973$.

22) Silberberg, I., Baer, R.L., Rosenthal, S.A. : The role of Langerhans cells in allergic contact hypersensitivity. A review of findings in man and guinea pigs. J. Invest. Dermatol., 66 : 210-217, 1976.

23) Silberberg, S.I., Thorbecke, G.J. : Contact hypersensitivity and Langerhans cells. J. Invest. Dermetol., $75: 61-67,1980$.

24) Toews, G.B., Bergstresser, P.R., Streilein, J. W. : Langerhans cells : Sentinels of skin associated lymphoid tissue. J. Invest. Dermatol., $75: 78-82,1980$.

25) Bos, I.R. \& Burkhardt, A. : Interepithelial cells of the oral mucosa. J. of oral Path., $9: 65-81$, 1980.

26) Newcomb, G.M., Seymour, G.J. and Powell, R.N. : Association between plaque accumulation and Langerhans cell number in the oral epithelium of attached gingiva. J. Clin. Periodontol., $9: 297-304,1982$.

27) DiFranco, C.F., Toto, P.D., Rowden, G., Gargiulo, A.W., Keene, J.J. and Connelly, E. : Identification of Langerhans cells in human gingival epithelium. J. Periodontol., $56: 48$ $54,1985$.

28) Niebauer, G., Krawsczyk, W.S., Kidd, R.L. and Wilgram, G.F. : Osmium zinic iodide reactive sites in the epidermal Langerhans cell. J. Cell Biol., 43 : 80-89, 1969.

29) Rodriguez, E.M. and Caorsi, I. : A second look at the ultrastructure of Langerhans cell of the human epidermis. J. Ultrastructure Res., 65 : 
279-295, 1978.

30) Falck, B., Agrup, G., Jacobsson, S., Rorsman, H., Rosengren, E., Sachner, K. and Ogren, M. : Uptake of L-dopa and functionally related aromatic amino acids into the Langerhans cells. J. Invest. Dermatol., 66 : 265, 1976.

31) Jarrett, A. and Riley, P.A. : Esterase activity in dendritic cells. Brit. J. Dermatol., $75: 79$ 81, 1963.

32) Zelickson, A.S., Mottaz, J.H. : Localization of gold chroride and adenosine triphosphatase in human Langerhans cells. J. Invest. Dermatol., $51:$ 365-372, 1968.

33) Mackenzie, I.C. and Squier, C.A. : Cytochemical identification of ATPase-positive Langerhans cells in EDTA separate sheets of mouse epidermis. Brit. J. Dermatol., 92 : 523-533, 1975.

34) Juhlin, L. and Shelley, W.B. : New staining techniques for the Langerhans cell. Acta Dermatovener, 57 : 289-296, 1977.

35) Cocchia, D., Michetti, F. and Donato, R. : Immunochemical and immunocytochemical localization of S-100 antigen in normal human skin. Nature, 294 : 85-87, 1981.

36) Nakajima, T., Watanabe, S., Sato, Y., Simosato, Y., Motoi, M and Lennert, K. : S-100 protein in Langerhans cells, interdigitating reticulum cells and histiocytosis $\mathrm{X}$ cells. Gann, 73 :
429-432, 1982.

37) Nakajima, T., Sato, Y., Watanabe, S., Simosato, Y., Ishihara, K. and Isobe, T. : Immunoelectron microscopical demonstration of S-100 protein in epidermal Langerhans cells. Biomedical Res., 3 : 226-231, 1982.

38) Fithian, E., Kung, P., Goldstein, G., Rubenfeld M., Fenoglio, C. and Edelson, R. : Reactivity of Langerhans cells with hibridoma antibody. Proc. Natl. Acad. Sci. USA, 78 : 2541-2544, 1981.

39) Katz, S.I., Tamaki, K., Sachs, D.H. : Epidermal Langerhans cells are derived from cells originating in the bone marrow. Nature, $282: 324-$ 326,1979 .

40) Tamaki, K., Stingl, G. and Katz, S.I. : The origin of Langerhans cells. J. Invest. Dermatol., 74 : 309-311, 1980.

41) Hoefsmit, E.C.M., Duijvestijn, A.M. and Kamperdijk, E.W.A. : Relation between Langerhans cells, veiled cells and interdigitating cells. Immunobiol., 161 : 255-265, 1982.

42) Gashnait, F. and Brenner, W. : Kinetics of epidermal Langerhans cells. J. Invest. Dermatol., $73: 566-569,1979$.

43）岡田 宏, 恵比須繁之, 福原弘喜, 島内英俊, 葛 西康宏, 脇田由美子 : 若年層にみられる歯周炎の 臨床ならびに免疫学的検討. 日本歯科評論, 514 : 125-134, 1985. 